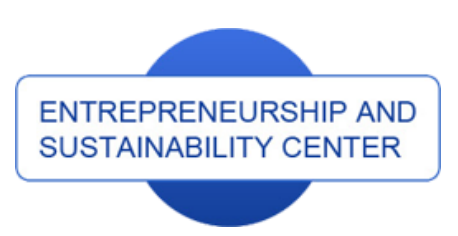

Publisher

http://jssidoi.org/esc/home
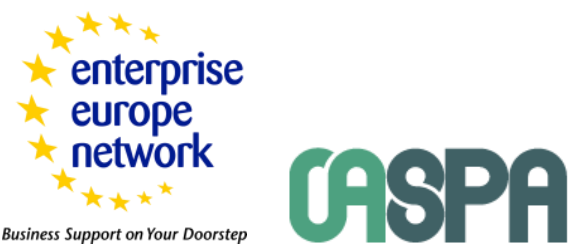

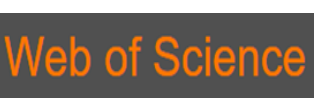

Clarivate
Analytics

\title{
A STUDY ON THE ANTECEDENTS OF ENTREPRENEURIAL INTENTIONS AMONG SAUDI STUDENTS
}

\author{
Mohammad Naushad \\ College of Business Administration, Prince Sattam Bin Abdulaziz University, Al-Kharj, Kingdom of Saudi Arabia (KSA) \\ E-mails:n.mohammad@psau.edu.sa
}

Received 16 September 2017; accepted 18 January 2018; published 30 March 2018

\begin{abstract}
The present study has developed and tested a model based on Theory of Planned Behavior (TPB) with addition of some psychological variables to figure out the antecedents of entrepreneurial intentions of Saudi undergraduate business students. A sample of 550 students were taken. Responses were collected by a self administered questionaire and analysed by using a univariate statistics and Partial Least Square (PLS) Structural Equation Modeling (SEM). The study has emerged with behavioral and personality antecedents (Attitude, Subjective Norm, Internal locus of control, need for achievement and propensity to take risk) of entrepreneurial intent among Saudi students. The results underpin the idea that personality factors along with the behavioral factors strengthen the predictibility of intentions to be involved in an entrepreneurial behavior.
\end{abstract}

Keywords: entrepreneurial intentions; Theory of Planned Behavior (TPB); Partial Least Square (PLS); Structural Equation Modeling (SEM); Saudi students.

Reference to this paper should be made as follows: Naushad, M. 2018. A study on the antecedents of entrepreneurial intentions among saudi students, Entrepreneurship and Sustainability Issues 5(3): 600-617. http://doi.org/10.9770/jesi.2018.5.3(14)

JEL Classifications: C3, D91, L2, L26

\section{Introduction}

Entrepreneurship is a vehicle of economic growth; an instrument that facilitates employment genration, innovation, and competitiveness; and a catalyst of social development. Promotion of entrepreneurship is now accorded national priorities by many countries, specifically among developing ones (Gird \& Bagraim, 2008; Karimi et al., 2015; Sulphey \& Alkahtani, 2017). Being appraised of the indispensibility of entrepreneurship for delevering all round economic growth development and employment, the United Nations has included its promotion in the Sustainable Development Goals under the head Education and Economic Growth (UN, 2015). 


\section{The International Journal}

ENTREPRENEURSHIP AND SUSTAINABILITY ISSUES

ISSN 2345-0282 (online) http://jssidoi.org/jesi/

2018 Volume 5 Number 3 (March)

http://doi.org/10.9770/jesi.2018.5.3(..)

Further, nurturing and encouraging entrepreneurship presents a solution to the employment issues - both among youth and adult population alike (Basheer \& Sulphey, 2017; Sulphey \& Alkahtani, 2017).

The largest economy in the Middle East and North Africa (MENA), Kingdom of Saudi Arabia (KSA) (IMF, 2017) gets its major revenue and contribution to GDP from oil sector. Being appraised of the need to strengthen and diversity the non-petroleum sector, the government of KSA has put forth several ambitious initiatives in its Ninth (2010-2014) and Tenth Development Plans (2017-2019) (Aloulou, 2016; Kayed \& Kabir Hassan, 2011; WAMDA, 2017). The "Vision 2030", an economic blue print for national economic growth looks towards entrepreneurship and private sector to take a leading role in economic development. It is expected that this focus will facilitate job creation and competitiveness. The introduction of the Small and Medium Enterprise Authority (SMEA) - recently branded as "Monsha'at"; signals the bright future of entrepreneurial ventures in KSA. As on date the government has implemented many initiatives, including large scale public awareness programs focused on the access to capital and support for startups. Further, "NEOM" a new city in line with Sillicon Valley is also planned to be instituted in the country. The importance accorded by KSA towards entrepreneurship can be judged from the allocation of $2.4 \%$ of GDP for its promotion (SAGIA, 2016). But dispite this hue and cry Saudi Arabia ranked 53 out of 66 in the recent GEM Report in the government entrepreneurship program (GEM, 2017). And 61 out of 66 ranks in the entrepreneurship education at school and and post school stage (GEM, 2017).

In the light of above background it is high time to measure the readiness of entrepreneurship among the population in KSA. The entrepreneurial intention must be inculcate first to develop the entrepreneurial behaviour, activities and culture as a whole. As it has been noted that entrepreneurial intentions are best predictors of entrepreneurial behaviors and activities (Aloulou, 2016; Kautonen et al., 2015; Krueger et al., 2000; Lüthje \& Franke, 2003). Moreover, Entrepreneurial Intention (EI) is considered as the sapling of an entrepreneurial tree and first step towards the creation of new venture (Iakovleva et al., 2011; Karimi et al., 2015). This is considered as one of the reasons for the present study. Moreover limited number of researches on the intentions of Saudi students (Ali, 2016; Almobaireek \& Manolova, 2012; Aloulou, 2016) is also a focal point for the present study.

The present study aims to ascertain the antecedents of entrepreneurial intentions among Saudi students. The study slant towards the intentions by combinitng the psychological variables with Ajzen (1985) TPB. The reliability and validity of outcome is ensured by the second generation anlytical tool, the Partial Least Square- Structural Equation Modelling (PLS-SEM). The organisation of the study is as follows. Section one present a comprenesive literature review sufficient for setting the theortical background and a conceptual model stating the hypothesis. The second section provides the insights of methodology, data collection and analysis. And the third section is about the results and discussions, limitations and scope for future research.

\section{Review of literature}

Predicting human behavior along with its all complexities is the most difficult phenomenon (Ajzen, 1991). It is more cumbursome when the behavior is rare, and hard to observe. However in human psychology, intention is proved to be the best predictor of human behavior (Krueger et al., 2000). Enterepeneurial behavior is also considered as the one of the planned behaviors (Kruger, 2000). Likely other human behaviors entrepreneurial behavior can also be predicted by intentions (Krueger et al., 2000; Lüthje \& Franke, 2003). Entrepreneurial Intention (EI) is the stepping stone for a comprehensive and stretched process of starting new ventures (Karimi et al., 2015). Theory of Planned Behavior propounded by Ajzen (1985) is identifed as the most pervasive, robust, widely used and coherent approach in predicting the entrepreneurial intent (Engle et al., 2010; Kautonen et al., 2015; Krueger Jr et al., 2000; Liñán \& Chen, 2009; Lüthje \& Franke, 2003; van Gelderen et al., 2008). TPB postulates that the following three independent and motivational constructs predict EI: 
The International Journal
ENTREPRENEURSHIP AND SUSTAINABILITY ISSUES

ISSN 2345-0282 (online) http://jssidoi.org/jesi/

2018 Volume 5 Number 3 (March)

http://doi.org/10.9770/jesi.2018.5.3(..)

1. Attitude towards behavior (ATD): This refers to the degree to which a person has a favourable or unfavourable evaluation of the behaviour in question (I. Ajzen \& Madden, 1986). Attitude according to Ajzen (1991) and Ajzen and Fishbein (2000) is a behavioural belief which has been shown approximately 50 percent of variance in intentions and approximately 30 percent in overall behaviour. Studies like, Schlaegel and Koenig (2014), Schwarz et al. (2009), Gelderen et al. (2008) and Kolvereid (1996) have tested the relevancy of attitude as a significant predictor and found it to be the significant.

2. Subjective norms (SN): This is the perceived social pressure to perform or not to perform a particular behaviour. It is based on two components: a. normative belief and b. motivation to comply with these beliefs (Ajzen \& Fishbein, 2000). An individual develops a belief and generate motivation from the family, friends and significant others who will approve or disapprove the decision of becoming an entrepreneur (Linen, 2008). Thus SN can be positive and negative depending upon the positivity and negativity of normative belief and motivation received (Aloulou, 2016; Karimi et al., 2016; Liñán \& Chen, 2009). The current study focuses on the positivity of SN towards entrepreneurship. SN is also found to mediate in formation of a positive attitude and the perceived behavioural control (Liñán, 2004; Liñán \& Chen, 2009).

3. Perceived behavioral control (PBC): This is the perception of ease or difficulty of performing certain behaviours (Ajzen, 1991). PBC is concerned with the sense of capacity to perform a particular behaviour. It is based on the notion that Individual usually choose to perform behaviours that they think they will be able to control and master (Moriano et al., 2012). It resembles with the Theory of Perceived Self-efficacy (Bandura, 1977; Hao et al., 2005; Moriano et al., 2012). Self-efficacy is considered to be a stronger predictor of EI (Armitage \& Conner, 2001). The determinants of PBC or self-efficacy have been vastly investigated by researchers (for instance (Hao et al., 2005; Pihie \& Bagheri, 2013; Piperopoulos \& Dimov, 2015; Winkler \& Case, 2014).

Several researchers have applied TPB on students' samples and confirmed its' predictability in multiple contexts and cultures (Autio et al., 2001; Iakovleva et al., 2011; Krueger et al., 2000; Liñán \& Chen, 2006; van Gelderen et al., 2008). These studies concluded that combining the three antecedents explain 30 to 45 percent of the variation in intentions. TPB in Kingdom of Saudi Arabia (KSA) context was tested by Ali (2016), Aloulou (2016), Almobaireek and Manolova (2012) on students samples and observed an overall variation of 40, 33.4 percent in explaining the entrepreneurial intentions (EIs) respectively. Considering all these studies, the following hypothesis are set for the sample of Saudi students.

H1: The three antecedents of TPB; Attitude towards behaviour (ATD), Subjective norms (SN) and Perceived Behavioural Control (PBC) together positively explain the EIs among Saudi Students.

H1a: ATD positively affects the EIs of Saudi Students.

H1b: SN positively affects the EIs of Saudi Students.

H1c: PBC positively affects the EIs of Saudi Students.

H2a: SN positively affects the attitude (ATD) of Saudi Students.

H2b: SN positively affects the Perceived Behavioural Control (PBC) of Saudi Students.

\section{Psychological characteristics and Entrepreneurial Intent:}

The role of personality traits or psychological characteristics like risk propensity, locus of control, need for achievements etc., in entrepreneurial behavior and new venture creation is an aspect that can never be overlooked (Zhao \& Seibert, 2006). Personality and personal characteristics of entrepreneurs are integral part of the multidimensional model of entrepreneurship (Espíritu-Olmos \& Sastre-Castillo, 2015; Zhao \& Seibert, 2006). 


\section{The International Journal}

ENTREPRENEURSHIP AND SUSTAINABILITY ISSUES

ISSN 2345-0282 (online) http://jssidoi.org/jesi/

2018 Volume 5 Number 3 (March)

http://doi.org/10.9770/jesi.2018.5.3(..)

However, only a week relationship has been found between psychological characteristics as a direct predictor of EI (Ferreira et al., 2012; Karimi et al., 2015). But when these are combined with the behavioral characteristics like attitude, subjective norms, perceived behavioral control etc.; there was found to be better relationship with entrepreneurial intentions (Altinay et al., 2012; Ferreira et al., 2012; Karimi et al., 2015; Nasip et al., 2017). The fact that meager amount of studies have only regressed the psychological characteristics with TPB constructs, has also proved to be a source of motivation for the current study. A number of studies have examined the relational relationship between psychological characteristics and TPB. A few such studies are reviewed in the following section and presented under various heads like internal locus of control, need for achievement, propensity of taking risk, etc.

1. Internal Locus of Control: Internal Locus of control (ILC) refers to the degree of perception of individuals about the events control. Earlier narratives on internal locus of control and entrepreneurial intent rendered inconsistent and conflicting evidences between internal locus of control and entrepreneurial intention (Ferreira et al., 2012; Gürol \& Atsan, 2006; Rauch \& Frese, 2007). There are several studies that confirmed that students with higher internal locus of control are high in entrepreneurial behavior, and EI (Gürol \& Atsan, 2006; Koh, 1996; Thomas \& Mueller, 2001). However, Ferreira et al. (2012), and Dinis et al. (2013) did not observe any significant relationship with EI. Rauch and Frese (2007) found a small effect of internal locus of control on entrepreneurial success, which indicate the presence of moderating and mediating variables. However, when ILC is regressed with attitude it was found to be significant because of its alignment with the definitions. People with high internal locus of control are likely to have more positive attitude towards entrepreneurship (Robinson et al., 1991). Moreover, they were found to be having high belief that they can establish a new venture with ease (Karimi et al., 2015). This notion presents an association between internal locus of control and PBC. Based on these the following hypotheses are framed:

H3a: Internal locus of control (ILC) positively affects the attitude (ATD) of Saudi Students in predicting the entrepreneurial intentions.

H3b: Internal locus of control (ILC) positively affects the perceived behavioural control (PBC) of Saudi Students in predicting the entrepreneurial intentions.

H3c: Internal locus of control (ILC) positively affects the Entrepreneurial Intentions (EIs) of Saudi Students.

2. Need for Achievements: Need for achievements (NFA) was first presented by McClelland (1961). He postulated that individuals with high desire for success would have a high propensity towards a high level of need of achievement. Due to this, such individuals are more likely to become entrepreneurs. An individual, high on need for achievement can thus be expected to have a positive attitude towards entrepreneurship (McClelland, 1987). Further, individual with a higher need for achievement appreciates personal responsibility, prefers solving problems unassisted, likes taking acceptable risks, and has a strong interest in the outcomes of their efforts or decisions (Sesen, 2013). People, high on this aspect relatively are more capable and high in ability to prevail under adverse circumstances (Karimi et al., 2015). Need for Achievement as a significant predictor of entrepreneurial intention has been identified in several studies (Altinay et al., 2012; Ferreira et al., 2012; Gürol \& Atsan, 2006; Koh, 1996; Rauch \& Frese, 2007). For instance, Rauch and Frese (2007) in their meta-analysis affirm a direct relationship between need for achievement and EI. Based on these, the following Hypothesis are framed:

H4a: Need for Achievements (NFA) positively affects the attitude (ATD) of Saudi students in predicting the entrepreneurial intentions. 
The International Journal

ENTREPRENEURSHIP AND SUSTAINABILITY ISSUES

ISSN 2345-0282 (online) http://jssidoi.org/jesi/

2018 Volume 5 Number 3 (March)

http://doi.org/10.9770/jesi.2018.5.3(..)

H4b: Need for Achievements (NFA) positively affects the Perceived Behavioural Control (PBC) of Saudi students in predicting the entrepreneurial intentions.

H4c: Need for Achievements (NFA) Positively affects the Entrepreneurial Intentions (EIs) of Saudi students.

3. Propensity to Risk: Risk taking or Propensity to take risk (PTR) has been one of the most important constituent of entrepreneurial personality. Many studies have identified propensity to take risk as one of the determinants of EI (Koh, 1996; Rauch \& Frese, 2007; Stewart \& Roth, 2001). Certain other studies, like Gürol and Atsan (2006), and Dinis et al. (2013) employed propensity to risk as an endogenous variable in EI models. Propensity to take risk is a capacity building characteristic, and provides a positive attitude and contribute towards self-efficacy of individuals (Zhao et al., 2005). Those who will be willing to take high risk will have a positive attitude towards entrepreneurship (Bygrave, 1989; Do Paço et al., 2011). Similarly one with a perception of relatively high difficulty in any event will be more interested to take part in that event. The following hypothesis are formulated based on the available literature:

H5a: Propensity to Risk (PTR) positively affects the attitude (ATD) of Saudi students in predicting the entrepreneurial intentions.

H5b: Propensity to Risk (PTR) positively affects the Perceived Behavioural Control (PBC) of Saudi students in predicting the entrepreneurial intentions.

H5c: Propensity to Risk (PTR) positively affects the Entrepreneurial Intentions (EIs) of Saudi students.

4. Self Confidence: Self-confidence is an individual's belief in his/her personal ability to organize and execute a specific set of tasks (Bygrave, 1989; Koh, 1996). It is an essential entrepreneurial characteristic (Robinson et al., 1991), and is related to other psychological characteristics such as internal locus of control, propensity to take risk and tolerance of ambiguity (Koh, 1996). Studies like Robinson et al. (1991) Dinis et al. (2013), Ferreira et al. (2012) and Nasip et al. (2017) found self-confidence a significant predictor entrepreneurial intentions. The hypotheses drafted for self-confidence are as under:

H6a: Self-Confidence (SC) positively affects the attitude (ATD) of Saudi students in predicting the entrepreneurial intentions.

H6b: Self-Confidence (SC) positively affects the Perceived Behavioural Control (PBC) of Saudi students in predicting the entrepreneurial intentions.

H6c: Self-Confidence (SC) positively affects the Entrepreneurial Intentions (EIs) of Saudi students.

Based on the review of literature, and the hypotheses derived therein, the proposed for the study can be seen in fig.1:

\section{Methodology}

Senior students (level five and above) of an undergraduate business program of a public university in KSA form the target population for the study. The sampling choice is coherent because of two reasons:

1. Business students are prospective entrepreneurs and most of the studies on EI are based on samples from amongst students e.g. Zhao et al. (2005); Lüthje and Franke (2003); Engle et al. (2010); Chen (2013); Krueger et al. (2000); Autio et al. (2001). 
2. KSA is a country where a large proportion of population aged between 15 and 30 years. Young people have more chances to involve in entrepreneurial activities.

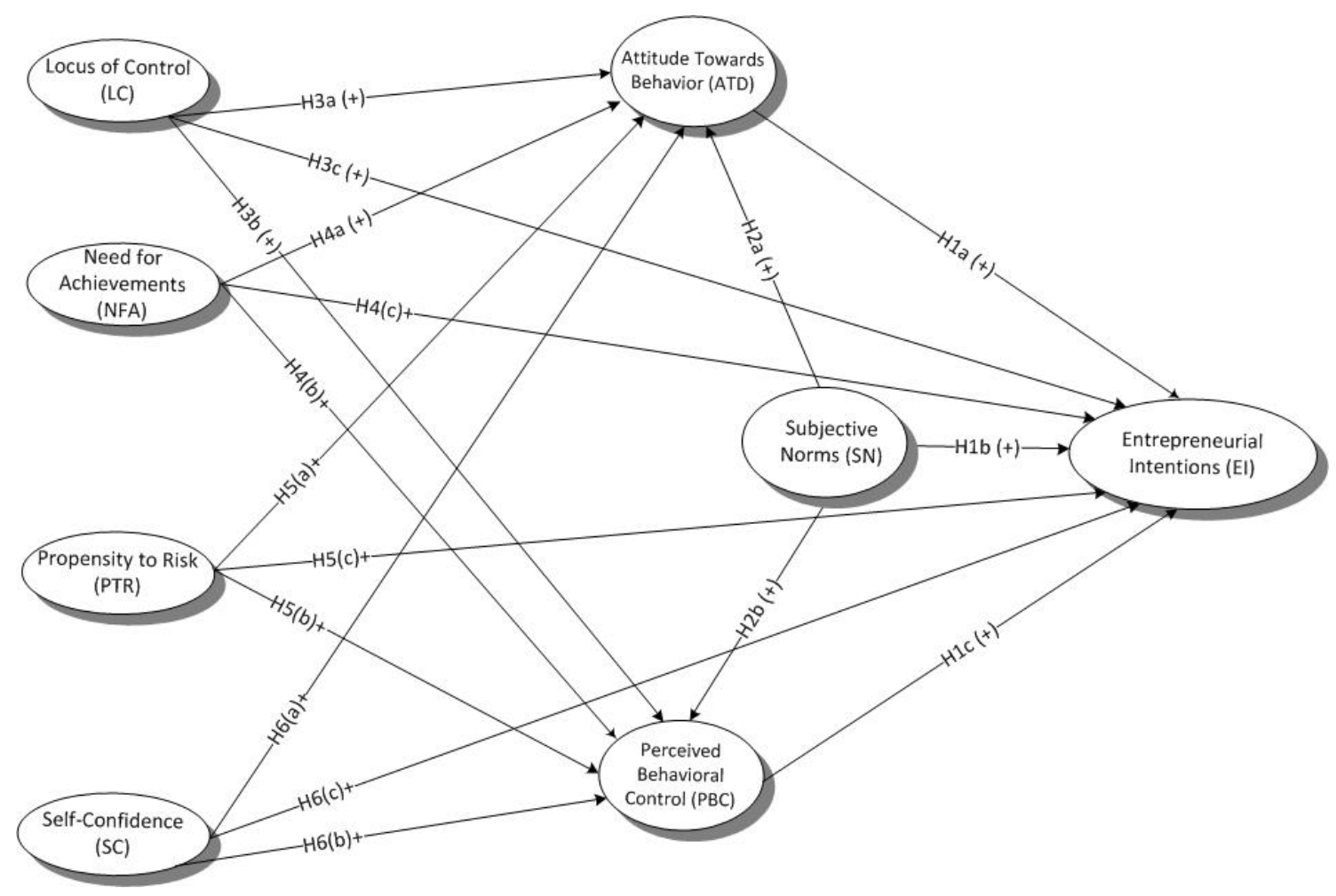

Fig.1. Proposed Model

Data for the study was collocated through a self-administered questionnaire. The questionnaire consisted of three sections. Section one solicited information about the demographic variables, section two consisted items pertained to EI variables (conceived from Linen Liñán and Chen (2009)); and section three was personality related variables (conceived from Koh (1996) and Zhao et al. (2005)). The items adopted from Liñán and Chen (2009) were on a seven point likert scale, while personality related items taken from Koh (1996) and Zhao et al. (2005) were on a 5 point likert scale where higher value indicate "Agree Strongly" and lower value "Disagree Strongly". A total of 600 questionnaires translated into Arabic language were distributed over a period of four months. 550 questionnaires were received duly filled in, making an overall response rate of 92 per cent. Data screening, cleaning and analysis were conducted with the help of IBM SPSS software. Missing value analysis were performed and values with greater than five per cent $(n>5 \%)$ were eradicated, and rest were replaced with a series median. The seven point likert scale items were downscaled to five point to resemble the whole data. The outliers were detected are removed. Subsequent to the above processes the data set consisted of 315 , which were ideal for Partial Least Square (PLS) or path coefficient analysis. Data sufficiency for path coefficient analysis was verified, and it was found to be sufficient by GPower software (Ringle et al., 2014). SmartPLS software was used for path coefficient analysis. The Table below presents the characteristics of the sample used in the study. 
Table 1. Sample Characteristics

\begin{tabular}{|c|c|}
\hline Data Type & Questionnaire administered data \\
\hline Population & Level 5 and above Business Undergraduate Students \\
\hline Sample Size & 550 \\
\hline Response Rate & 92 percent \\
\hline Final Data for Analysis & 315 \\
\hline Male Respondents & 243 \\
\hline Female Respondents & 72 \\
\hline & Source: Research's compilation
\end{tabular}

\section{Results and Discussions:}

\section{Descriptive Analysis}

The descriptive statistics are presented in Table 2. The results suggest that students are inclined towards the entrepreneurial behavior, with higher mean for $\mathrm{EI}(\mathrm{M}=4.416, \mathrm{SD}=0.837)$. In contrary to EI, Self Confidence has the lowest mean $(\mathrm{M}=3.148, \mathrm{SD}=0.560)$ indicating that students are not confident enough to be an entrepreneur. One more interesting fact that emerges from the descriptive statistics is that the EI and its antecedents has higher mean with low variance relatively to the personality variables of entrepreneur (see table-2).

Table 2. Descriptive Statistics of Summated Scales

\begin{tabular}{|l|c|c|c|c|c|c|c|c|}
\hline & Min & Max & Range & Mean & Mdn & SD & Kurtosis & Skewness \\
\hline EI & 1.000 & 5.000 & 4.000 & 4.416 & 4.750 & 0.837 & 3.160 & -1.802 \\
\hline ATD & 1.400 & 5.000 & 3.600 & 4.371 & 4.600 & 0.711 & 2.297 & -1.519 \\
\hline SN & 1.000 & 5.000 & 4.000 & 3.923 & 4.000 & 0.914 & -0.020 & -0.714 \\
\hline PBC & 1.000 & 5.000 & 4.000 & 3.788 & 4.000 & 1.035 & -0.218 & -0.769 \\
\hline LC & 1.429 & 5.000 & 3.571 & 3.515 & 3.429 & 0.605 & 0.521 & 0.202 \\
\hline NFA & 2.000 & 4.333 & 2.333 & 3.403 & 3.333 & 0.465 & -0.253 & -0.043 \\
\hline PTR & 1.833 & 4.833 & 3.000 & 3.391 & 3.333 & 0.496 & 0.096 & 0.137 \\
\hline SC & 1.833 & 5.000 & 3.167 & 3.148 & 3.000 & 0.560 & 0.114 & 0.432 \\
\hline
\end{tabular}

Source: Research's compilation

\section{The Measurement Model}

The measuring model evaluation or outer model assessment is based on the confirmation of three important measurements namely, convergent validity, internal consistency reliability and discriminant validity (Ringle et al., 2014). The convergent validities are obtained by the observations of the Average Variance Extracted (AVEs). According to (Henseler et al., 2009) the AVEs values for all measurements should exceed the threshold limit of 0.50. Those having values below 0.50 were dropped from the measurement model. Figure 2 presents the measurement model of the present study in SmartPLS. The values of AVEs greater are than 0.50. Thus the model can be considered to have convergent validities. 


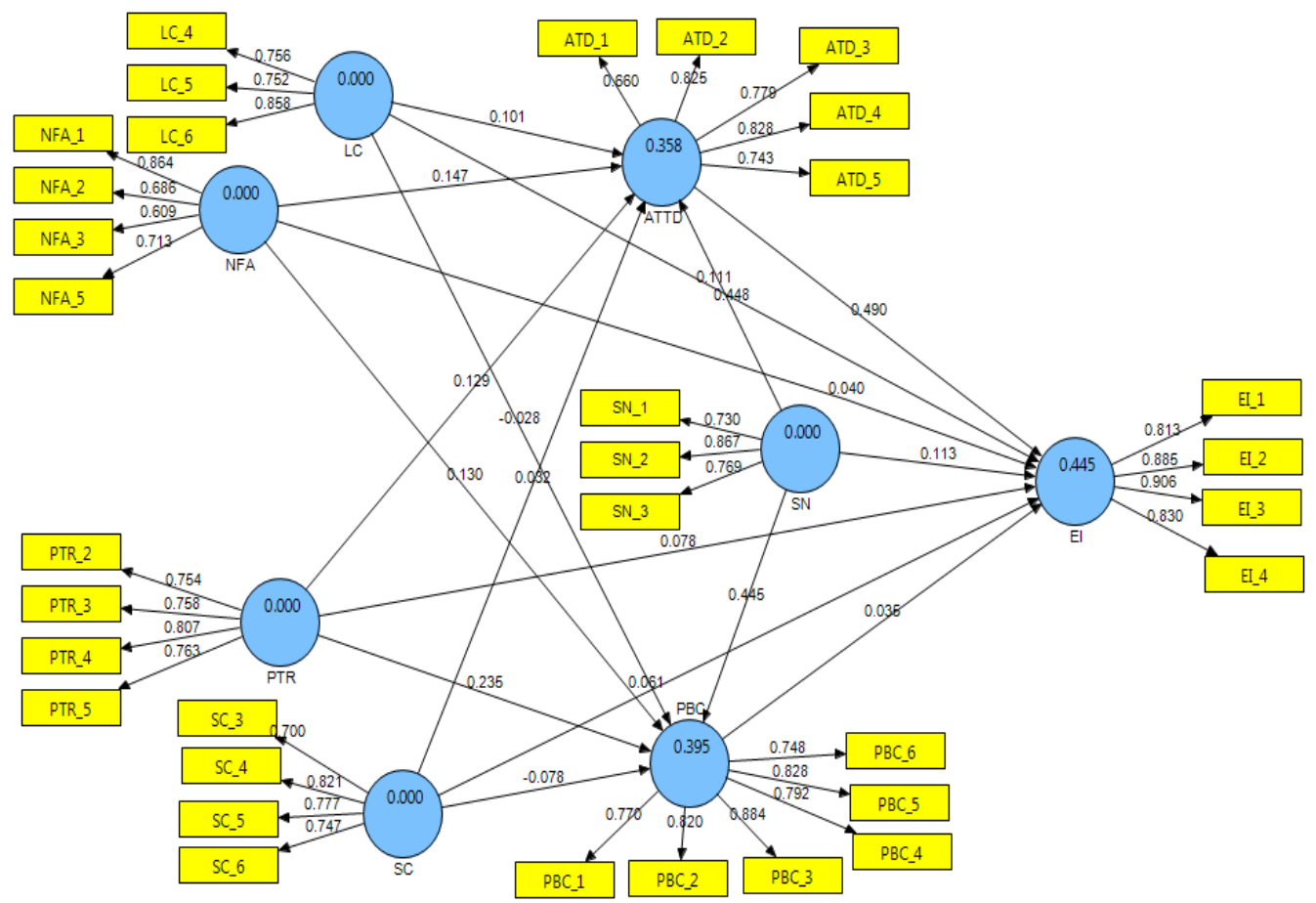

Fig.2. Measurement Model

Source: Research's compilation

The internal consistency values predicted by the Croanbach's Alpha (CA) and Composite Reliability (CR) are used to evaluate the un-biasness of the samples, or reliability of the answers in the groups. In the given cases, the CA values for various cases range from 0.70 to 0.89 (Table-3), which fits into the threshold limit of Cronbach's Alpha (CA> 0.7). The CR values above 0.70 are considered satisfactory, as proposed by (Hair et al., 2010). The composite reliabilities of different measures were found to range from 0.81 to 0.92 , which satisfactorily meets the threshold. Table 3 thus demonstrates that the CA and CR values are adequate.

Table 3. Descriptive Statistics of Summated Scales

\begin{tabular}{|c|c|c|c|}
\hline & Composite Reliability & R Square & Cronbach's Alpha \\
\hline ATTD & 0.878 & 0.358 & 0.825 \\
\hline EI & 0.919 & 0.417 & 0.881 \\
\hline LC & 0.833 & 0.000 & 0.704 \\
\hline NFA & 0.812 & 0.000 & 0.693 \\
\hline PBC & 0.919 & 0.396 & 0.893 \\
\hline PTR & 0.854 & 0.000 & 0.774 \\
\hline SC & 0.848 & 0.000 & 0.769 \\
\hline SN & 0.833 & 0.000 & 0.699 \\
\hline
\end{tabular}


The International Journal

ENTREPRENEURSHIP AND SUSTAINABILITY ISSUES

ISSN 2345-0282 (online) http://jssidoi.org/jesi/

2018 Volume 5 Number 3 (March)

http://doi.org/10.9770/jesi.2018.5.3(..)

Table 4 and 5 reports the results of discriminant validity of the measure scale. The results indicate that the constructs are the independent from one another (Hair et al., 2016). Table 4 demonstrates that the square root of AVEs for all the latent variables (values in the matrix diagonals). It can be seen that all the values are greater than the inter-constructs correlations. Thus it can be construed that the results supports the discriminant validity of the scales as proposed by Fornell and Larcker (1981). The extracted factors and cross loadings of all indicator items to their concerned latent construct are presented in Table 5. These results indicate that all items loaded on their respective construct from a lower bound of 0.70 to an upper bound of 0.90 on their respective construct than on any other. This provides an additional support to confirm the discriminant validity.

Table 4. Inter-correlations of Variable Construct as per Fornell and Larcker (1981) Criterion

\begin{tabular}{|c|c|c|c|c|c|c|c|c|}
\hline & ATTD & EI & LC & NFA & PBC & PTR & SC & SN \\
\hline ATTD & 0.770 & & & & & & & \\
\hline EI & 0.635 & 0.859 & & & & & & \\
\hline LC & 0.320 & 0.345 & 0.790 & & & & & \\
\hline NFA & 0.370 & 0.341 & 0.527 & 0.723 & & & & \\
\hline PBC & 0.558 & 0.425 & 0.243 & 0.368 & 0.808 & & & \\
\hline PTR & 0.324 & 0.322 & 0.444 & 0.486 & 0.399 & 0.771 & & \\
\hline SC & -0.158 & -0.102 & -0.145 & -0.258 & -0.279 & -0.316 & 0.764 & \\
\hline SN & 0.525 & 0.423 & 0.195 & 0.260 & 0.537 & 0.198 & -0.219 & 0.791 \\
\hline \multicolumn{70}{|c|}{ Source: Research's compilation } \\
\hline
\end{tabular}

Table 5. Outer Model Loadings and Cross Loadings

\begin{tabular}{|l|c|c|c|c|c|c|c|c|}
\hline & ATTD & EI & LC & NFA & PBC & PTR & SC & SN \\
\hline ATD_1 & $\mathbf{0 . 6 6 0}$ & 0.390 & 0.211 & 0.293 & 0.414 & 0.262 & -0.184 & 0.419 \\
\hline ATD_2 & $\mathbf{0 . 8 2 5}$ & 0.542 & 0.264 & 0.322 & 0.485 & 0.289 & -0.160 & 0.404 \\
\hline ATD_3 & $\mathbf{0 . 7 7 9}$ & 0.508 & 0.256 & 0.308 & 0.358 & 0.208 & -0.043 & 0.368 \\
\hline ATD_4 & $\mathbf{0 . 8 2 8}$ & 0.517 & 0.228 & 0.239 & 0.469 & 0.252 & -0.140 & 0.408 \\
\hline ATD_5 & $\mathbf{0 . 7 4 3}$ & 0.473 & 0.268 & 0.259 & 0.419 & 0.233 & -0.081 & 0.421 \\
\hline EI_1 & 0.527 & $\mathbf{0 . 8 1 1}$ & 0.304 & 0.249 & 0.290 & 0.268 & -0.065 & 0.312 \\
\hline EI_2 & 0.581 & $\mathbf{0 . 8 8 6}$ & 0.303 & 0.273 & 0.329 & 0.266 & -0.076 & 0.335 \\
\hline EI_3 & 0.550 & $\mathbf{0 . 9 0 6}$ & 0.303 & 0.310 & 0.423 & 0.294 & -0.094 & 0.409 \\
\hline EI_4 & 0.523 & $\mathbf{0 . 8 3 0}$ & 0.274 & 0.341 & 0.418 & 0.278 & -0.115 & 0.394 \\
\hline LC_4 & 0.187 & 0.238 & $\mathbf{0 . 7 4 8}$ & 0.430 & 0.176 & 0.433 & -0.099 & 0.096 \\
\hline LC_5 & 0.258 & 0.220 & $\mathbf{0 . 7 6 3}$ & 0.362 & 0.137 & 0.277 & -0.106 & 0.162 \\
\hline LC_6 & 0.298 & 0.340 & $\mathbf{0 . 8 5 5}$ & 0.457 & 0.249 & 0.360 & -0.134 & 0.190 \\
\hline NFA_1 & 0.340 & 0.341 & 0.506 & $\mathbf{0 . 8 5 7}$ & 0.332 & 0.423 & -0.205 & 0.245 \\
\hline NFA_2 & 0.263 & 0.184 & 0.355 & $\mathbf{0 . 7 1 0}$ & 0.297 & 0.365 & -0.294 & 0.183 \\
\hline NFA_3 & 0.171 & 0.174 & 0.202 & $\mathbf{0 . 6 1 5}$ & 0.254 & 0.303 & -0.220 & 0.181 \\
\hline NFA_5 & 0.272 & 0.271 & 0.427 & $\mathbf{0 . 6 8 9}$ & 0.153 & 0.295 & 0.005 & 0.124 \\
\hline PBC_1 & 0.425 & 0.271 & 0.195 & 0.312 & $\mathbf{0 . 7 7 0}$ & 0.339 & -0.233 & 0.459 \\
\hline PBC_2 & 0.477 & 0.332 & 0.181 & 0.296 & $\mathbf{0 . 8 2 0}$ & 0.296 & -0.142 & 0.452 \\
\hline PBC_3 & 0.479 & 0.329 & 0.200 & 0.306 & $\mathbf{0 . 8 8 4}$ & 0.328 & -0.235 & 0.487 \\
\hline PBC_4 & 0.335 & 0.265 & 0.166 & 0.263 & $\mathbf{0 . 7 9 3}$ & 0.260 & -0.275 & 0.405 \\
\hline PBC_5 & 0.417 & 0.353 & 0.184 & 0.284 & $\mathbf{0 . 8 2 8}$ & 0.317 & -0.267 & 0.383 \\
\hline PBC_6 & 0.541 & 0.481 & 0.243 & 0.314 & $\mathbf{0 . 7 4 7}$ & 0.375 & -0.204 & 0.408 \\
\hline
\end{tabular}


The International Journal

ENTREPRENEURSHIP AND SUSTAINABILITY ISSUES

ISSN 2345-0282 (online) http://jssidoi.org/jesi/

2018 Volume 5 Number 3 (March)

http://doi.org/10.9770/jesi.2018.5.3(..)

\begin{tabular}{|l|c|c|c|c|c|c|c|c|}
\hline PTR_2 & 0.270 & 0.255 & 0.341 & 0.431 & 0.344 & $\mathbf{0 . 7 5 9}$ & -0.278 & 0.174 \\
\hline PTR_3 & 0.196 & 0.212 & 0.249 & 0.340 & 0.256 & $\mathbf{0 . 7 5 6}$ & -0.274 & 0.050 \\
\hline PTR_4 & 0.279 & 0.259 & 0.387 & 0.358 & 0.342 & $\mathbf{0 . 8 1 0}$ & -0.192 & 0.181 \\
\hline PTR_5 & 0.237 & 0.261 & 0.377 & 0.361 & 0.270 & $\mathbf{0 . 7 5 6}$ & -0.240 & 0.182 \\
\hline SC_3 & -0.049 & -0.042 & -0.052 & -0.190 & -0.152 & -0.150 & $\mathbf{0 . 7 0 5}$ & -0.111 \\
\hline SC_4 & -0.103 & -0.059 & -0.066 & -0.141 & -0.205 & -0.185 & $\mathbf{0 . 8 2 5}$ & -0.197 \\
\hline SC_5 & -0.093 & -0.055 & -0.068 & -0.118 & -0.223 & -0.214 & $\mathbf{0 . 7 8 3}$ & -0.199 \\
\hline SC_6 & -0.191 & -0.128 & -0.209 & -0.306 & -0.242 & -0.355 & $\mathbf{0 . 7 3 8}$ & -0.150 \\
\hline SN_1 & 0.413 & 0.291 & 0.205 & 0.200 & 0.339 & 0.121 & -0.098 & $\mathbf{0 . 7 3 0}$ \\
\hline SN_2 & 0.501 & 0.429 & 0.147 & 0.228 & 0.457 & 0.216 & -0.167 & $\mathbf{0 . 8 6 7}$ \\
\hline SN_3 & 0.310 & 0.260 & \multicolumn{7}{|c|}{ 0.118 } & 0.184 & 0.476 & 0.115 & -0.259 & $\mathbf{0 . 7 6 9}$ \\
\hline
\end{tabular}

\section{Structural Model Assessment}

Once the reliability and validity of latent variables are established in a structural model, the next step is the assessment of structural or inner model. To run the final model bootstrapping technique has been used on 315 data points with 5,000 valid sub-samples. The results of initial bootstrapping are given in Table 6. The paths LC $>$ ATTD, LC $\rightarrow$ PBC, NFA $\rightarrow$ EI, PBC $\rightarrow$ EI, PTR $\rightarrow$ EI, SC $\rightarrow$ ATTD and SC $>$ EI are found to be not significant ( $\mathrm{p}>.10)$, and subsequently excluded from the original model. Upon exclusions the remaining significant paths are maintained, where level of significance is considered on different levels $(\mathrm{p} \leq 0.01, \mathrm{p} \leq 0.05$ and $\mathrm{p} \leq 0.10$ ). The Final bootstrapping results are reported in Table 7 .

Table 6. Initial Bootstrapping Results

\begin{tabular}{|c|c|c|c|c|c|}
\hline & $\begin{array}{c}\text { Original } \\
\text { Sample }\end{array}$ & $\begin{array}{c}\text { Sample } \\
\text { Mean }\end{array}$ & SD & SE & $\mathbf{t}$ \\
\hline ATTD -> EI & 0.490 & 0.493 & 0.069 & 0.069 & $7.118^{* * *}$ \\
\hline LC -> ATTD & 0.101 & 0.106 & 0.065 & 0.065 & $1.539 \mathrm{~ns}$ \\
\hline LC -> EI & 0.112 & 0.112 & 0.051 & 0.051 & $2.194 * *$ \\
\hline LC -> PBC & -0.028 & -0.026 & 0.059 & 0.059 & $0.469 \mathrm{~ns}$ \\
\hline NFA -> ATTD & 0.147 & 0.147 & 0.067 & 0.067 & $2.198 * *$ \\
\hline NFA -> EI & 0.040 & 0.039 & 0.072 & 0.072 & $0.555 \mathrm{~ns}$ \\
\hline NFA -> PBC & 0.131 & 0.131 & 0.061 & 0.061 & $2.130 * *$ \\
\hline PBC -> EI & 0.035 & 0.035 & 0.055 & 0.055 & $0.646 \mathrm{~ns}$ \\
\hline PTR -> ATTD & 0.129 & 0.127 & 0.060 & 0.060 & $2.151 * *$ \\
\hline PTR -> EI & 0.078 & 0.075 & 0.051 & 0.051 & $1.528 \mathrm{~ns}$ \\
\hline PTR -> PBC & 0.235 & 0.232 & 0.061 & 0.061 & $3.877 * * *$ \\
\hline SC -> ATTD & 0.032 & 0.027 & 0.047 & 0.047 & $0.680 \mathrm{~ns}$ \\
\hline SC -> EI & 0.061 & 0.058 & 0.044 & 0.044 & $1.395 \mathrm{~ns}$ \\
\hline SC -> PBC & -0.078 & -0.084 & 0.043 & 0.043 & $1.831^{*}$ \\
\hline SN -> ATTD & 0.448 & 0.446 & 0.057 & 0.057 & $7.834 * * *$ \\
\hline SN -> EI & 0.113 & 0.114 & 0.052 & 0.052 & $2.155^{* *}$ \\
\hline SN -> PBC & 0.445 & 0.445 & 0.049 & 0.049 & $9.006 * * *$ \\
\hline $\begin{array}{l}\text { Notes: n=315. Significant at } * * * 0.01 \text { level (p<01), } \\
\text { and *0.10 level. ns= not significant. }\end{array}$ & & & & \\
\hline
\end{tabular}


Table 7. Final bootstrapping results

\begin{tabular}{|c|c|c|c|c|c|}
\hline & $\begin{array}{c}\text { Original } \\
\text { Sample } \\
\end{array}$ & $\begin{array}{c}\text { Sample } \\
\text { Mean }\end{array}$ & SD & SE & $\mathbf{t}$ \\
\hline ATTD -> EI & 0.524 & 0.526 & 0.065 & 0.065 & $8.090 * * *$ \\
\hline LC $->$ EI & 0.157 & 0.159 & 0.046 & 0.046 & $3.397 * * *$ \\
\hline NFA $->$ ATTD & 0.182 & 0.186 & 0.066 & 0.066 & $2.762 * * *$ \\
\hline NFA -> PBC & 0.123 & 0.125 & 0.056 & 0.056 & $2.182 * *$ \\
\hline PTR -> ATTD & 0.147 & 0.148 & 0.058 & 0.058 & $2.532 * *$ \\
\hline PTR -> PBC & 0.225 & 0.225 & 0.057 & 0.057 & $3.930 * * *$ \\
\hline $\mathrm{SC}->\mathrm{PBC}$ & -0.078 & -0.085 & 0.042 & 0.042 & $1.885^{*}$ \\
\hline SN $->$ ATTD & 0.448 & 0.446 & 0.058 & 0.058 & $7.757 * * *$ \\
\hline $\mathrm{SN} \rightarrow \mathrm{EI}$ & 0.117 & 0.118 & 0.048 & 0.048 & $2.469 * *$ \\
\hline $\mathrm{SN}->\mathrm{PBC}$ & 0.444 & 0.443 & 0.050 & 0.050 & $8.966 * * *$ \\
\hline \multicolumn{6}{|c|}{$\begin{array}{l}\text { Notes: } \mathrm{n}=315 . \text { Significant at } * * * 0.01 \text { level }(\mathrm{p}<0.01),{ }^{* *} 0.05 \text { level }(\mathrm{p}<0.05) \\
\text { and } * 0.10 \text { level. }\end{array}$} \\
\hline
\end{tabular}

The relationship between the constructs and the coefficients obtained from structural model will be considered as robust if coefficients are bigger than 0.2 (Chin, 1998). Notably, the total effects of an independent variable over the dependent variable are always bigger because of interacting indirect effect. The direct, indirect and total effects are reported in Table 8. Only two constructs namely, SN and NFA had indirect effect on EI of the population in the study. As per the criteria of Chin (1998), attitude and subjective norms has robust effects on EI $(\beta>0.2)$. Among the psychological variables, only Locus of control and need for achievement has direct medium and indirect small effects on EI. Among psychological variables only propensity to risk has the big effect on PBC. Other variables have medium and small effects on attitude and perceived behavioural control. More importantly SN has a robust effect on the other antecedents of PTB (Table 8).

Table 8. Direct and Indirect effect Table

\begin{tabular}{|c|c|c|c|}
\hline & Direct effect & Indirect effect & Total effect \\
\hline ATTD -> EI & 0.524 & - & 0.524 \\
\hline LC -> EI & 0.157 & - & 0.157 \\
\hline NFA -> ATTD & 0.182 & - & 0.182 \\
\hline NFA -> EI & Ns & 0.072 & 0.072 \\
\hline NFA -> PBC & 0.131 & - & 0.131 \\
\hline PTR -> EI & Ns & 0.068 & 0.068 \\
\hline PTR -> ATTD & 0.129 & - & 0.129 \\
\hline PTR -> PBC & 0.235 & - & 0.235 \\
\hline SC -> PBC & -0.078 & - & -0.078 \\
\hline SN -> ATTD & 0.448 & - & 0.448 \\
\hline SN -> EI & 0.113 & 0.220 & 0.332 \\
\hline SN -> PBC & 0.445 & - & 0.445 \\
\hline \multicolumn{2}{|c|}{ Source: Research's compilation }
\end{tabular}


The Assessment of the structural model is incomplete without discussing the goodness of fit (GOF) statistics. The model discussed explains overall variation of 43.6 percent based on SN, ATR and PBC. The significance of structural coefficients and the size of effects provide the guidelines for research hypothesis results. The results of hypothesis can be presented as follows:

$\begin{array}{ll}\text { H1a: } & \text { ATTD -> EI } \\ \text { H1b: } & \text { SN -> EI } \\ \text { H1c: } & \text { PBC -> EI } \\ \text { H2a: } & \text { SN -> ATTD } \\ \text { H2b: } & \text { SN -> PBC } \\ \text { H3a: } & \text { LC -> ATTD } \\ \text { H3b: } & \text { LC -> PBC } \\ \text { H3c: } & \text { LC -> EI } \\ \text { H4a: } & \text { NFA -> ATTD } \\ \text { H4b: } & \text { NFA -> PBC } \\ \text { H4c: } & \text { NFA -> EI } \\ \text { H5a: } & \text { PTR -> ATTD } \\ \text { H5b: } & \text { PTR -> PBC } \\ \text { H5c: } & \text { PTR -> EI } \\ \text { H6a: } & \text { SC -> ATTD } \\ \text { H6b: } & \text { SC -> PBC } \\ \text { H6c: } & \text { SC -> EI }\end{array}$

Figure 3 presents the final model, with the effects and explained variances in the endogenous constructs.

\section{Discussions}

The study confirms the congruence of psychological characteristics with TPB and its' antecedents. Moreover it also affirms the applicability, generalizability and acceptance of TPB as a predictor of entrepreneurial intentions by extending it to one more country and culture. This has been confirmed with the help of a second generation quantitative tool.

The results revealed significant relationships between EI and its three motivational constructs. When taken together it explains the notably high per cent (43.6 per cent) of variation than other studies in the Saudi context (Ali, 2016; Almobaireek \& Manolova, 2012; Aloulou, 2016). In the present study attitude and SN are identified as the significant predictors of EI which indicate that students have a positive approach towards the entrepreneurship and are more likely to take inspiration from peers, friends, relatives, teachers and in total from society to become the entrepreneur in future. Thus social pressures also act like a trigger to the students for becoming future entrepreneurs (Moriano et al., 2012). The results of the study indicate attitude towards entrepreneurship as the strongest predictor of EI are in line with the other studies (Liñán \& Chen, 2009; Nabi et al., 2011; Schlaegel \& Koenig, 2014) conducted in different culture and context. Moreover the findings in the present study do not cite any significant relationship between PBC and EI. This seems to be in contrast to the findings of other studies, e.g. Liñán and Chen (2009), Engle et al. (2010), Iakovleva et al. (2011). However the results are not tend to be totally different studies like, Do Paço et al. (2011), Ferreira et al. (2012), Engle et al. (2010) found significantly minimal or no influence of PBC on EI. The other studies were conducted in the developed countries which conclude that people seems to be more certain about their success and their work (Karimi et al., 2015).

Out of four personality factors, considered for the present study, only two namely NFA and PTR relates to the attitude. It indicates that need for achievement contribute to form a positive attitude which leads to the intention to be involved in entrepreneurial behavior. PTR specify that the students are having a high propensity of positive 
The International Journal

ENTREPRENEURSHIP AND SUSTAINABILITY ISSUES

ISSN 2345-0282 (online) http://jssidoi.org/jesi/

2018 Volume 5 Number 3 (March)

http://doi.org/10.9770/jesi.2018.5.3(..)

attitude towards the risk which signify that they are willing to take risk. On the other hand, the NFA to PBC is in a same line of NFA to attitude, which indicates that high NFA could be translated into a perception of perceived easiness to start an enterprise. Further, more risk taking propensity will make it easier for them to start the business in future. The results provide a strong support to the earlier thoughts that emphasize that personality factors should be indeed incorporated into social-cognitive models of intentions and behavior (Ferreira et al., 2012; Karimi et al., 2015; Lüthje \& Franke, 2003). The results of the study are also in line with those showing the effects of psychological variables on EI (Dinis et al., 2013; Do Paço et al., 2011; Gürol \& Atsan, 2006; Koh, 1996; Nasip et al., 2017; Rauch \& Frese, 2007; Sesen, 2013) etc. The Study has several practical and policy implications. Based on the findings of the present study the educational and Training programs must be designed to develop, nurture and enhance the personality and behavioral antecedents of students emerged from the current study.

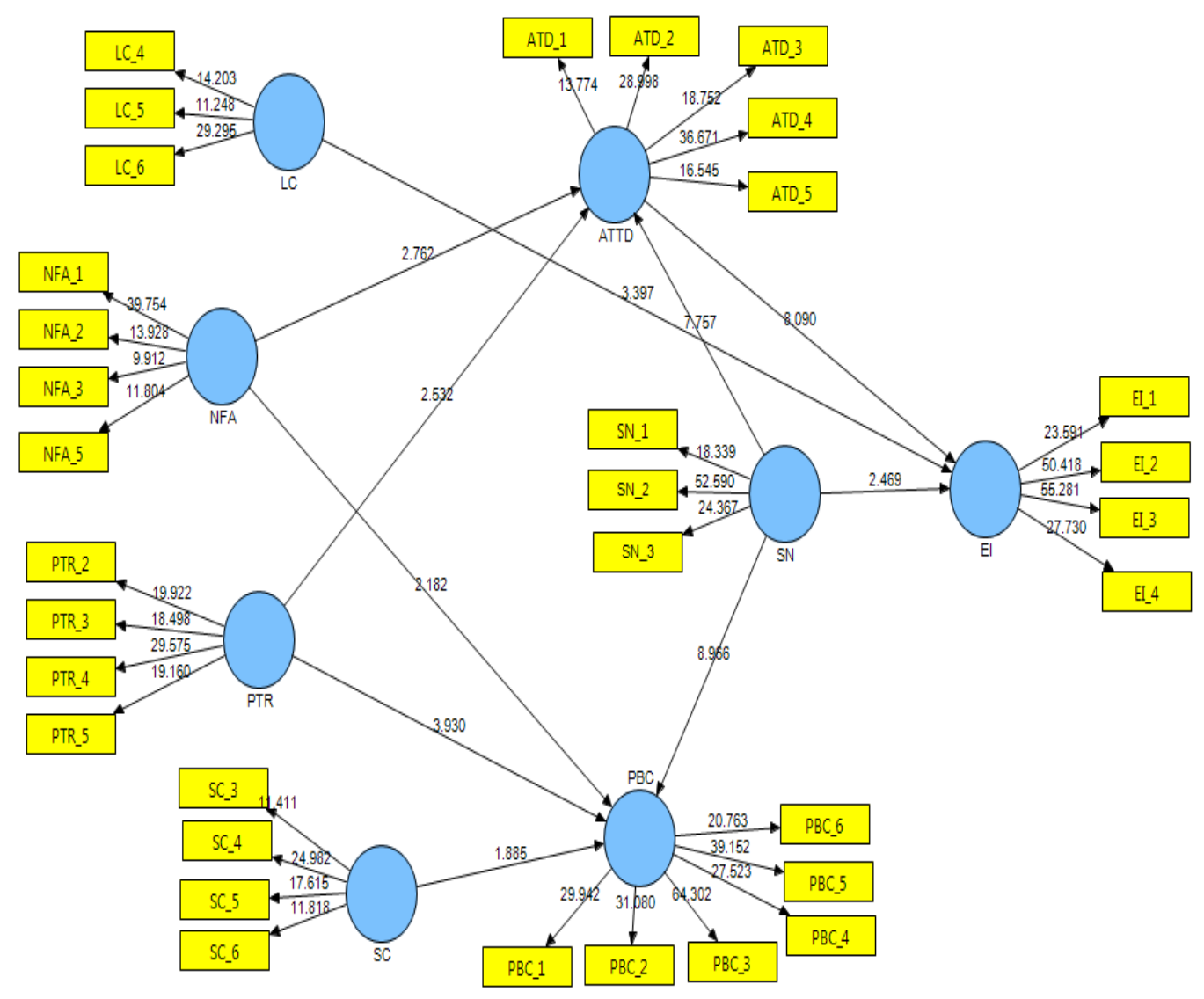

Fig.3. Final model

Source: Research's compilation

The study add one more argument to the literature that only personality factors are also equally important in identifying the intentions of students. Notably, the study was conducted on a sample that did not received any entrepreneurial training program. Therefore the new and introductory programs must focus on individual variables to develop further like subjective norm can be improved by means of developing an ecosystem which conjoint the networks of entrepreneurs at the regional and national level. At the institutional level opportunities 
must be developed for networking with entrepreneurs, students entrepreneurial clubs, guest lectures from renowned entrepreneurs, case study dissemination etc. Similarly a positive attitude towards entrepreneurship must be molded in the educational institutions. In this way the "VISION 2030" of KSA will be considered as a game changing initiative but the transformation of vision into action require a thorough thinking and work from the side of academicians and researchers.

\section{Conclusion, Suggestions, Limitations and Future Scope for the Study}

The present study aimed to investigate the antecedents of entrepreneurial intents of Saudi undergraduate business students by incorporating the personality characteristics (Internal Locus of Control (ILC), Self Confidence (SC), Need for Achievement (NFA) and Propensity to take risk (PTR)) into the TPB. A model (by combining the behavioral and psychological variables) was prepared and tested in this study through PLS (SEM). The Study explored whether and if so, the extent to which these distal factors relate to the motivational factors of EI of students in Saudi Arabian context. The Motivation for the study emerges from the fact that the Behavioral factors are relatively less stable than personality traits and can be changed both across time and situations in virtue of the individual's interaction with the environment (Robinson et al., 1991). The study finds that subjective norm and attitude are the significant predictors of EI among the students in KSA. On the other hand perceived behavioral control did not show any impact over the intentions. Among the personality antecedents only internal locus of control has a direct impact over the intention. The other personality related constructs namely NFA and PTR relates to the attitude and perceived behavioral control.

There are certain limitations to the study. The data collected for the study is a cross sectional data, a longitudinal data is preferred more to draw the firm conclusions. Moreover the data has been collected from a sample of undergraduate business students of a public university in KSA, which suffer from the insufficiency of the samples to make the findings generally applicable.

Some possible directions for future research may be highlighted. The replication of the study using the methodological aspects in other public and private universities of KSA will generate more generalized results. The theoretical model used in the study can be tested and replicated in other context and culture.

\section{References}

Ajzen. (1985). From intentions to actions: A theory of planned behavior Action control (pp. 11-39): Springer.

Ajzen. (1991). The theory of planned behavior. Organizational Behavior and Human Decision Processes, 50(2), 179-211. http://dx.doi.org/10.1016/0749-5978(91)90020-T.

Ajzen, \& Fishbein, M. (2000). Attitudes and the Attitude-Behavior Relation: Reasoned and Automatic Processes. European Review of Social Psychology, 11(1), 1-33. http://dx.doi.org/10.1080/14792779943000116.

Ajzen, I., \& Madden, T. J. (1986). Prediction of goal-directed behavior: Attitudes, intentions, and perceived behavioral control. Journal of Experimental Social Psychology, 22(5), 453-474. http://dx.doi.org/10.1016/0022-1031(86)90045-4.

Ali, T. B. (2016). Explaining the intent to start a business among Saudi Arabian University Students. International Review of Management and Marketing, 6(2).

Almobaireek, W. N., \& Manolova, T. S. (2012). Who wants to be an entrepreneur? Entrepreneurial intentions among Saudi university students. African Journal of Business Management, 6(11), 4029-4040. 
The International Journal

ENTREPRENEURSHIP AND SUSTAINABILITY ISSUES

ISSN 2345-0282 (online) http://jssidoi.org/jesi/

2018 Volume 5 Number 3 (March)

http://doi.org/10.9770/jesi.2018.5.3(..)

Aloulou, W. J. (2016). Predicting entrepreneurial intentions of final year Saudi university business students by applying the theory of planned behavior. Journal of Small Business and Enterprise Development, 23(4), 1142-1164. https://doi.org/10.1108/JSBED-02-2016$\underline{0028}$

Altinay, L., Madanoglu, M., Daniele, R., \& Lashley, C. (2012). The influence of family tradition and psychological traits on entrepreneurial intention. International Journal of Hospitality Management, 31(2), 489-499. https://doi.org/10.1016/j.ijhm.2011.07.007.

Armitage, C. J., \& Conner, M. (2001). Efficacy of the theory of planned behaviour: A meta-analytic review. The British Journal of Social Psychology, 40, 471-499. https://doi.org/10.1348/014466601164939

Autio, E., H. Keeley, R., Klofsten, M., G. C. Parker, G., \& Hay, M. (2001). Entrepreneurial Intent among Students in Scandinavia and in the USA. Enterprise and Innovation Management Studies, 2(2), 145-160. http://dx.doi.org/10.1080/14632440110094632.

Bandura, A. (1977). Self-efficacy: toward a unifying theory of behavioral change. Psychological review, 84(2), 191.

Basheer, A. H., \& Sulphey, M. M. (2017). Entrepreneurship curriculum in management programmes: Benchmarking with the curricula of top international universities Entrepreneurship Education: Experiments with Curriculum, Pedagogy and Target Groups (pp. 121-134).

Bygrave, W. D. (1989). The entrepreneurship paradigm: a philosophical look at its research methodologies. Entrepreneurship: Theory and Practice, 14(1), 7 .

Chen, L. (2013). IT Entrepreneurial Intention among College Students: An Empirical Study. Journal of Information Systems Education, 24(3), 233-243. https://www.learntechlib.org/p/156717/.

Dinis, A., do Paço, A., Ferreira, J., Raposo, M., \& Gouveia Rodrigues, R. (2013). Psychological characteristics and entrepreneurial intentions among secondary students. Education + Training, 55(8/9), 763-780. http://dx.doi.org/10.1108/ET-06-2013-0085.

Do Paço, A. M., Finisterra, Ferreira, J. M., Raposo, M., Rodrigues, R. G., \& Dinis, A. (2011). Behaviours and entrepreneurial intention: Empirical findings about secondary students. Journal of International Entrepreneurship, 9(1), 20-38. http://dx.doi.org/10.1007/s10843-010$\underline{0071-9}$.

Engle, R. L., Dimitriadi, N., Gavidia, J. V., Schlaegel, C., Delanoe, S., Alvarado, I., Wolff, B. (2010). Entrepreneurial intent: A twelve-country evaluation of Ajzen's model of planned behavior. International Journal of Entrepreneurial Behavior \& Research, 16(1), 3557. http://dx.doi.org/10.1108/13552551011020063.

Espíritu-Olmos, R., \& Sastre-Castillo, M. A. (2015). Personality traits versus work values: Comparing psychological theories on entrepreneurial intention. Journal of Business Research, 68(7), 1595. http://dx.doi.org/10.1016/j.jbusres.2015.02.001.

Ferreira, J. J., Raposo, M. L., Gouveia Rodrigues, R., Dinis, A., \& do Paço, A. (2012). A model of entrepreneurial intention: An application of the psychological and behavioral approaches. Journal of Small Business and Enterprise Development, 19(3), 424-440. http://dx.doi.org/10.1108/14626001211250144.

Fornell, C., \& Larcker, D. F. (1981). Structural equation models with unobservable variables and measurement error: Algebra and statistics. Journal of marketing research, 382-388.

Gelderen, M. v., Brand, M., Praag, M. v., Bodewes, W., Poutsma, E., \& Gils, A. v. (2008). Explaining entrepreneurial intentions by means of the theory of planned behaviour. Career Development International, 13(6), 538-559. http://dx.doi.org/10.1108/13620430810901688.

GEM. (2017). Global Entrepreneurship Monitor (GEM) 2016/2017-Global Report 2016/17.

Gird, A., \& Bagraim, J. J. (2008). The theory of planned behaviour as predictor of entrepreneurial intent amongst final-year university students. South African Journal of Psychology, 38(4), 711-724. https://doi.org/10.1177/008124630803800410

Gürol, Y., \& Atsan, N. (2006). Entrepreneurial characteristics amongst university students: Some insights for entrepreneurship education and training in Turkey. Education \& Training, 48(1), 25-38. http://dx.doi.org/10.1108/00400910610645716

Hair, J. F., Anderson, R. E., Babin, B. J., \& Black, W. C. (2010). Multivariate data analysis: A global perspective (Vol. 7): Pearson Upper Saddle River, NJ. 
Hair, J. F., Hult, G. T. M., Ringle, C., \& Sarstedt, M. (2016). A primer on partial least squares structural equation modeling (PLS-SEM): Sage Publications.

Hao, Z., Seibert, S. E., \& Hills, G. E. (2005). The Mediating Role of Self-Efficacy in the Development of Entrepreneurial Intentions. Journal of Applied Psychology, 90(6), 1265-1272. http://dx.doi.org/10.1037/0021-9010.90.6.1265.

Henseler, J., Ringle, C. M., \& Sinkovics, R. R. (2009). The use of partial least squares path modeling in international marketing New challenges to international marketing (pp. 277-319): Emerald Group Publishing Limited.

Iakovleva, T., Kolvereid, L., \& Stephan, U. (2011). Entrepreneurial intentions in developing and developed countries. Education + Training, 53(5), 353-370. http://dx.doi.org/10.1108/00400911111147686.

IMF. (2017). Regional Economic Outlook Middle East and Central Asia; October 2017.

Karimi, S., Biemans, H. J. A., Lans, T., Chizari, M., \& Mulder, M. (2016). The Impact of Entrepreneurship Education: A Study of Iranian Students' Entrepreneurial Intentions and Opportunity Identification. Journal of Small Business Management, 54(1), 187-209. http://dx.doi.org/10.1111/jsbm.12137.

Karimi, S., Biemans, H. J. A., Naderi Mahdei, K., Lans, T., Chizari, M., \& Mulder, M. (2015). Testing the relationship between personality characteristics, contextual factors and entrepreneurial intentions in a developing country: personality, context and intentions. International Journal of Psychology, n/a-n/a. http://dx.doi.org/10.1002/ijop.12209.

Kautonen, T., Gelderen, M., \& Fink, M. (2015). Robustness of the Theory of Planned Behavior in Predicting Entrepreneurial Intentions and Actions. Entrepreneurship Theory and Practice, 39(3), 655-674. http://dx.doi.org/10.1111/etap.12056.

Kayed, R. N., \& Kabir Hassan, M. (2011). Saudi Arabia's economic development: entrepreneurship as a strategy. International Journal of Islamic and Middle Eastern Finance and Management, 4(1), 52-73.

Koh, H. C. (1996). Testing hypotheses of entrepreneurial characteristics: A study of Hong Kong MBA students. Journal of Managerial Psychology, 11(3), 12-25. http://dx.doi.org/10.1108/02683949610113566.

Kolvereid, L. (1996). Prediction of employment status choice intentions. Entrepreneurship: Theory and Practice, $21(1), 47$.

Krueger Jr, N. F., Reilly, M. D., \& Carsrud, A. L. (2000). Competing models of entrepreneurial intentions. Journal of Business Venturing, 15(5-6), 411-432. http://dx.doi.org/10.1016/S0883-9026(98)00033-0.

Liñán, F. (2004). Intention-based models of entrepreneurship education. Piccolla Impresa/Small Business, 3(1), 11-35.

Liñán, F., \& Chen, Y.-W. (2006). Testing the entrepreneurial intention model on a two-country sample.

Liñán, F., \& Chen, Y.-W. (2009). Development and Cross-Cultural Application of a Specific Instrument to Measure Entrepreneurial Intentions. Entrepreneurship Theory and Practice, 33(3), 593-617. http://dx.doi.org/10.1111/j.1540-6520.2009.00318.x

Lüthje, C., \& Franke, N. (2003). The 'making' of an entrepreneur: testing a model of entrepreneurial intent among engineering students at MIT. R\&D Management, 33(2), 135-147. http://dx.doi.org/10.1111/1467-9310.00288.

McClelland, D. C. (1961). Achieving society: Simon and Schuster.

McClelland, D. C. (1987). Characteristics of successful entrepreneurs. The journal of creative behavior, 21(3), 219-233. https://doi.org/10.1002/j.2162-6057.1987.tb00479.x

Moriano, J. A., Gorgievski, M., Laguna, M., Stephan, U., \& Zarafshani, K. (2012). A Cross-Cultural Approach to Understanding Entrepreneurial Intention. Journal of Career Development, 39(2), 162-185. http://dx.doi.org/10.1177/0894845310384481.

Nabi, G., Liñán, F., Iakovleva, T., Kolvereid, L., \& Stephan, U. (2011). Entrepreneurial intentions in developing and developed countries. Education+ Training, 53(5), 353-370. https://doi.org/10.1108/00400911111147686 
The International Journal
ENTREPRENEURSHIP AND SUSTAINABILITY ISSUES

ISSN 2345-0282 (online) http://jssidoi.org/jesi/

2018 Volume 5 Number 3 (March)

http://doi.org/10.9770/jesi.2018.5.3(..)

Nasip, S., Amirul, S. R., Stephen Laison, S., Jr., \& Tanakinjal, G. H. (2017). Psychological characteristics and entrepreneurial intention: A study among university students in North Borneo, Malaysia. Education \& Training, 59(7/8), 825. https://doi.org/10.1108/ET-10-2015-0092

Pihie, Z. A. L., \& Bagheri, A. (2013). Self-Efficacy and Entrepreneurial Intention: The Mediation Effect of Self-Regulation. Vocations and Learning, 6(3), 385-401. http://dx.doi.org/10.1007/s12186-013-9101-9.

Piperopoulos, P., \& Dimov, D. (2015). Burst Bubbles or Build Steam? Entrepreneurship Education, Entrepreneurial Self-Efficacy, and Entrepreneurial Intentions. Journal of Small Business Management, 53(4), 970-985. http://dx.doi.org/10.1111/jsbm.12116.

Rauch, A., \& Frese, M. (2007). Let's put the person back into entrepreneurship research: A meta-analysis on the relationship between business owners' personality traits, business creation, and success. European Journal of Work and Organizational Psychology, 16(4), 353385. http://dx.doi.org/10.1080/13594320701595438.

Ringle, C. M., Silva, D. d., \& Diógenes de Souza, B. (2014). Structural Equation Modeling with the Smartpls. REMark: Revista Brasileira de Marketing, 13(2), 56-73. http://dx.doi.org/10.5585/remark.v13i2.2717.

Robinson, P. B., Stimpson, D. V., Huefner, J. C., \& Hunt, H. K. (1991). An attitude approach to the prediction of entrepreneurship. Entrepreneurship: Theory and Practice, 15(4), 13.

SAGIA. (2016). Facts and Statistics Saudi Arabia: Saudi Arabian General Investment Authority.

Schlaegel, C., \& Koenig, M. (2014). Determinants of Entrepreneurial Intent: A Meta-Analytic Test and Integration of Competing Models. Entrepreneurship Theory and Practice, 38(2), 291-332. http://dx.doi.org/10.1111/etap.12087.

Schwarz, E. J., Wdowiak, M. A., Almer-Jarz, D. A., \& Breitenecker, R. J. (2009). The effects of attitudes and perceived environment conditions on students' entrepreneurial intent: An Austrian perspective. Education \& Training, 51(4), 272-291. http://dx.doi.org/10.1108/00400910910964566.

Sesen, H. (2013). Personality or environment? A comprehensive study on the entrepreneurial intentions of university students. Education + Training, 55(7), 624-640. http://dx.doi.org/10.1108/ET-05-2012-0059.

Stewart, W. H., \& Roth, P. L. (2001). Risk Propensity Differences between Entrepreneurs and Managers: A Meta-Analytic Review. Journal of Applied Psychology, 86(1), 145-153. http://dx.doi.org/10.1037/0021-9010.86.1.145.

Sulphey, M., \& Alkahtani, N. S. (2017). Economic security and sustainability through social entrepreneurship: the current Saudi scenario. Journal of Security \& Sustainability Issues, 6(3). https://doi.org/10.9770/jssi.2017.6.3(12)

Thomas, A. S., \& Mueller, S. L. (2001). Culture and entrepreneurial potential: A nine country study of locus of control and innovativeness. Journal of Business Venturing, 16(1), 51-75. http://dx.doi.org/10.1016/S0883-9026(99)00039-7.

UN, G. A. (2015). Transforming our world: The 2030 agenda for sustainable development: A/RES/70/1, 21 October.

Van Gelderen, M., Brand, M., van Praag, M., Bodewes, W., Poutsma, E., \& van Gils, A. (2008). Explaining entrepreneurial intentions by means of the theory of planned behaviour. Career Development International, 13(6), 538-559. http://dx.doi.org/10.1108/13620430810901688.

WAMDA. (2017). The Kingdom of Saudi Arabia: Status of the entrepreneurship ecosystem.

Winkler, C., \& Case, J. R. (2014). Chicken or egg: entrepreneurial self-efficacy and entrepreneurial intentions revisited. Journal of Business and Entrepreneurship, 26(1), 37-62.

Zhao, H., \& Seibert, S. E. (2006). The Big Five Personality Dimensions and Entrepreneurial Status: A Meta-Analytical Review. Journal of Applied Psychology, 91(2), 259-271. http://dx.doi.org/10.1037/0021-9010.91.2.259.

Zhao, H., Seibert, S. E., \& Hills, G. E. (2005). The Mediating Role of Self-Efficacy in the Development of Entrepreneurial Intentions. Journal of Applied Psychology, 90(6), 1265-1272. http://dx.doi.org/10.1037/0021-9010.90.6.1265. 
The International Journal

ENTREPRENEURSHIP AND SUSTAINABILITY ISSUES

ISSN 2345-0282 (online) http://jssidoi.org/jesi/

2018 Volume 5 Number 3 (March)

http://doi.org/10.9770/jesi.2018.5.3(..)

Dr. Mohammad Naushad is the Assistant Professor of Business and Management at College of Business Administration, Prince Sattam Bin Abdulaziz University, KSA. He has worked on the various topics of entrepreneurship, teaching, learning and educational quality issues. He is currently working on multiple issues of entrepreneurship studies.

ORCID ID: https://orcid.org/0000-0003-4421-3422.

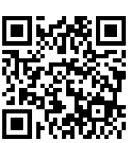

Register for an ORCID ID:

https://orcid.org/register

Copyright (C) 2018 by author(s) and VsI Entrepreneurship and Sustainability Center

This work is licensed under the Creative Commons Attribution International License (CC BY).

http://creativecommons.org/licenses/by/4.0/

c) (i) Open Access 